\title{
ПРОБЛЕМИ ЗБЕРІГАННЯ МЕДИЧНОЇ ТА БІОЛОГІЧНОЇ ІНФОРМАЦІЇ
}

\author{
В. В. Петров, О. П. Мінцер ${ }^{1}$, \\ А. А. Крючин, Є. А. Крючина ${ }^{2}$ \\ Інститут проблем реєстрації інфрормації НАН України \\ ${ }^{1}$ Національна медична академія післядипломної освіти імені П. Л. Шупика \\ ${ }^{2}$ Київська міська клінічна лікарня № 10
}

\begin{abstract}
Представлено аналіз використання медичної та біологічної інформації в інфрормаційно-аналітичних системах. Наведені дані свідчать про швидке зростання представленої у цифровому вигляді такої інорормації, показана важливість і необхідність забезпечення її довготермінового зберігання. Представлена інсрормація про носії інсоормації, що можуть забезпечити надійне та довготермінове зберігання медичної та біологічної інсрормації. Особливу увагу приділено аналізу характеристик перспективних типів оптичних носіїв для довготермінового зберігання інформації.
\end{abstract}

Ключові слова: медична та біологічна інорормація, довготермінове зберігання даних, молекулярно-генетичні дані, міграція даних, персоніфрікована медицина.

\section{PROBLEMS OF STORAGE OF MEDICAL AND BIOLOGICAL INFORMATION}

\author{
V. V. Petrov, O. P. Mintser ${ }^{1}$, \\ A. A. Kryuchyn, Ye. A. Kryuchyna² \\ Institute for information recordings NAS of Ukraine \\ ${ }^{1}$ Shupyk National Medical Academy of Postgraduate Education \\ ${ }^{2}$ Kyiv city clinical hospital No. 10
}

\begin{abstract}
The analysis of the use of medical and biological information in information-analytical systems is presented, the given data testify to the rapid growth of such information presented in digital form, the importance and necessity of its longterm storage is shown. Information about media carriers that can provide reliable and long-term storage of medical and biological information is presented. Particular attention is paid to the analysis of the characteristics of promising types of optical media for long-term storage of information.
\end{abstract}

Key words: medical and biological information, long-term data storage, molecular genetic data, data migration, personalized medicine.

\section{ПРОБЛЕМЫ ХРАНЕНИЯ МЕДИЦИНСКОЙ И БИОЛОГИЧЕСКОЙ ИНФОРМАЦИИ}

\author{
В. В. Петров, О. П. Минцер ${ }^{1}$, \\ А. А. Крючин, Е. А. Крючина \\ Институт проблем регистрации инсрормации НАН Украины \\ ${ }^{1}$ Национальная медицинская академия последипломного образования имени П. Л. Шупика \\ ${ }^{2}$ Киевская городская клиническая больница № 10
}

\begin{abstract}
Представлен анализ использования медицинской и биологической инфрормации в инсормационно-аналитических системах. Приведенные данные свидетельствуют о быстром росте представленной в цифровом виде такой информации, показана важность и необходимость обеспечения ее долгосрочного хранения. Представлена инорормация о носителях инсормации, которые могут обеспечить надежное и долгосрочное хранение медицинской и биологической инорормации. Особое внимание уделено анализу характеристик перспективных типов оптических носителей для долговременного хранения информации.
\end{abstract}

Ключевые слова: медицинская и биологическая инсормация, долгосрочное хранение данных, молекулярногенетические данные, миграция данных, персонифицированная медицина.

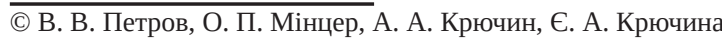


Вступ. Медична та біологічна інформація має важливе значення для організації надання високоякісних послуг, збереження даних про біологічне різноманіття. Обсяги медичної та біологічної інформації, що підлягає довготерміновому зберіганню, постійно збільшуються. Особливо швидко зростають обсяги молекулярно-генетичних даних, розшифрованої генетичної інформації, що підлягає довготерміновому зберіганню [16]. Сучасні дослідження в галузі медицини, зокрема вивчення генетичних основ складних захворювань, вимагають комплексного аналізу великого масиву клінічної інформації та молекулярно-генетичних даних, що характеризують індивідуальні особливості організму. Одними з найважливіших комп’ютерних баз біологічних даних у загальнонауковому плані $є$ глобальні бази даних про структуру біологічних молекул і геномів різних організмів, в яких міститься найрізноманітніша інформація про живі системи. Створення комп’ютерних баз біологічних даних, в яких міститься найрізноманітніша інформація про живі системи, є необхідним інструментом вирішення комплексних питань оцінювання біорізноманіття окремих регіонів, потенційних ризиків для них, формалізації оцінювання їх масштабів, планування способів відновлення та збереження біорізноманіття.

Мета дослідження: створення ефективної інфраструктури зберігання медичної та біологічної інформації.

Результати та їх обговорення. Особливості зберігання медичної та біологічної інформації. Завдання зберігання медичних даних (історія хвороби, результати обстеження пацієнтів тощо) ускладнюється низкою аспектів:

- юридичною значимістю інформації;

- великим обсягом (наприклад, результати томографії можуть становити кілька гігабайт);

- неоднорідністю, складністю структури даних [7].

Основною особливістю медичної інформації є неоднорідність (різнорідність) даних, що можуть бути представлені як в стандартизованому електронному вигляді, наприклад, дані комп’ютерної томографії, рентгенографії, ультразвукових методів обстеження, так і в довільному — наприклад, записи лікаря.

Дослідники визначають, що клінічна інформація як у паперовому, так і в електронному вигляді $€$ цінним матеріалом — національним надбанням, яке заслуговує на довгострокове зберігання в архівах, із забезпеченням як зберігання даних, так і оперативного доступу до них. Неможливо обмежувати термін зберігання такої інформації 10-15 роками
[11]. Важливість забезпечення довготривалого зберігання бази даних медичної та біологічної інформації відзначена вже в перших дослідженнях зі створення медичних інформаційних систем [13]. Стандарти зберігання медичних даних передбачають тривале зберігання з гарантією їх цілісності та максимально оперативного доступу до них. Розроблений ще в 1980-х роках уніфікований формат для передавання та зберігання медичних образів DICOM (Digital Image and Communication in Medicine) формалізує створення, зберігання, передавання та візуалізацію результатів рентгенівських, ультразвукових і томографічних досліджень, різних документів. Перехід від технологій отримання, зберігання й аналізу медичних зображень, що базувалися на використанні рентгенівських плівок, до цифрових зображень і цифрової системи PACS (Picture Archiving and Communication Systems), яка забезпечує роботу з ними, привів до значного збільшення обсягу інформації, котра отримується в процесі діагностичних досліджень.

Підвищення вимог до раннього виявлення та надійної діагностики захворювань призвело до вдосконалення старих і появи принципово нових технологій отримання медичних зображень [2-4]. При цьому збільшилася кількість досліджень і різко зросла кількість зображень, одержуваних при кожному сеансі обстеження. Зберігання, передавання та аналіз такої кількості зображень стає часто складним завданням. У табл. 1 наведено умовні середньостатистичні дані про кількість проведених досліджень за рік, розміри та кількість знімків при одному дослідженні в середньому європейському центрі променевої діагностики. За рік може накопичуватися великий обсяг інформації: більше 10 Тб даних [4] (табл. 1).

Наступним кроком у технології оброблення та зберігання медичних зображень стало створення розподіленої PACS-системи, призначеної для створення єдиного інформаційного простору даних, отриманих під час радіологічних обстежень пацієнтів, для всіх лікувальних закладів регіону за рахунок створення єдиної паспортної реєстрації, забезпечення взаємодії локальних і центральних PACS-систем та забезпечення доступу користувачів у межах їх повноважень до інформації пацієнтів. Розподілена PACS складається з локальних серверів PACS кожного лікувального закладу та центрального сервера. Сервери PACS представляють собою апаратно-програмні комплекси, що складаються з одного або декількох фізичних серверів, систем 
Обсяг інформації при проведенні променевої діагностики

\begin{tabular}{|c|c|c|c|c|}
\hline Тип дослідження & $\begin{array}{c}\text { Обсяг } \\
\text { зображення } \\
\text { (Кб) }\end{array}$ & $\begin{array}{c}\text { Кількість } \\
\text { досліджень } \\
\text { за рік }\end{array}$ & $\begin{array}{c}\text { Кількість зобра- } \\
\text { жень для одного } \\
\text { дослідження }\end{array}$ & $\begin{array}{c}\text { Обсяг даних } \\
\text { за рік (Гб) }\end{array}$ \\
\hline Комп’ютерна томографія & 524 & 15000 & 100 & 786 \\
\hline Магнітно-резонансна томографія & 65 & 6000 & 100 & 39 \\
\hline Ультразвук & 262 & 15000 & 36 & 141,48 \\
\hline Ядерна медицина & 65 & 6000 & 64 & 24,96 \\
\hline Пересувні рентгенівські апарати & 10000 & 45000 & 1 & 450 \\
\hline Lat Chest & 10000 & 6000 & 1 & 60 \\
\hline PA i Lateral & 10000 & 35000 & 2 & 700 \\
\hline PA Chest & 10000 & 30000 & 1 & 300 \\
\hline Мамографія & 32000 & 12500 & 4 & 1600 \\
\hline Мієлографія & 10000 & 700 & 10 & 70 \\
\hline Інтервенційні процедури & 10000 & 1000 & 15 & 150 \\
\hline Ангіограма & 1000 & 6000 & 300 & 1800 \\
\hline Флебограма & 8000 & 500 & 10 & 40 \\
\hline Урологія & 8000 & 3000 & 6 & 144 \\
\hline Флуороскопія & 1000 & 5000 & 8 & 40 \\
\hline Angio (non-neuro) & 1000 & 8000 & 300 & 2400 \\
\hline Angio-neuro & 1000 & 5500 & 300 & 1650 \\
\hline \multicolumn{3}{|l|}{ Всього досліджень за рік } & 200200 & \\
\hline \multicolumn{4}{|l|}{ Всього Мб за рік } & 10395440 \\
\hline
\end{tabular}

зберігання даних, системного та прикладного програмного забезпечення [8].

Необхідно відзначити ще одну особливість, пов'язану з використанням медичної інформації, - забезпечення великої швидкості доступу до інформації, оскільки від цього може залежати своєчасність і правильність призначеного пацієнту лікування.

Стандарти зберігання медичних даних передбачають довготермінове зберігання з гарантією цілісності даних і максимально оперативним доступом. Необхідність же в довготерміновому зберіганні даних, що відносяться до медичної статистики, клінічної практики, медико-біологічного експерименту, очевидна, бо медицина і практична охорона здоров’я є галузями інформаційно-накопичувальними, а ціна клінічних даних настільки висока, що виправдані навіть високі витрати на організацію достовірного тривалого зберігання. Необхідність довготермінового зберігання все зростаючих обсягів критично важливих даних змушує медичні установи шукати раціональні варіанти управління такими даними та сховищами. Медичному персоналу необхідно створити умови для підвищення продуктивності та розширити можливості доступу до медичних карток і медичних знімків пацієнтів.

Обсяги медичної та біологічної інформації, що підлягає довготерміновому зберіганню, будуть збільшуватися й при впроваджені генетичного паспорту людини. Створення та зберігання генетичного паспорту людини, у якої виявлено певну генетичну схильність до найбільш значущих і поширених хвороб, дозволяє перейти до так званої персоніфікованої медицини, включає в себе пошук генетично зумовленої схильності до розвитку тих або інших хвороб, так званих слабких місць організму, задля попередження хвороби чи хоча б мінімізації її наслідків. Персоніфікована медицина - це модель 
організації медичної допомоги, що базується на виборі діагностичних, лікувальних і профілактичних засобів із урахуванням генетичних, фізіологічних, біохімічних та інших особливостей пацієнта. Персоніфікована медицина передбачає створення для кожного пацієнта генетичного паспорта - електронного документа, в якому представлена інформація про ДНК. Ця інформація повинна зберігатися протягом життя пацієнта [22]. Персоніфікована медицина - це нова галузь сучасної медицини, при якій розробляються та застосовуються методи лікування, «скроєні» спеціально під конкретного пацієнта. Серед напрямів застосування положень персоніфікованої медицини в сучасних умовах виділяють: перехід від традиційної клінічної до персоніфікованої діагностики захворювання з урахуванням індивідуальних показників пацієнта, зокрема використання біомаркерів різної молекулярної природи, 3 подальшим збереженням біоматеріалу протягом усього життя пацієнта; передбачення на основі геномних даних ймовірності виникнення того чи іншого захворювання з розробленням профілактичної індивідуальної схеми; ідентифікація потенційних фармако-терапевтичних мішеней для селективного впливу вже на ініціальній стадії патологічного процесу; вибір тактики лікування з урахуванням індивідуальних показників пацієнтів; моніторинг лікування за допомогою біомаркерів. Посилення ролі клінічної фармакології та створення генетично обгрунтованих алгоритмів персоніфікованої медицини підвищить ефективність і безпеку фармакотерапії. Уся інформація повинна бути систематизованою, зберігатися відповідно до її класифікації, ділових вимог і періоду зберігання. Відповідні строки та умови зберігання, використання рекомендованих методів лікування забезпечать керування, захист та доступність інформації [15].

Необхідно відзначити існування великого масиву медичної та біологічної інформації, що створюється завдяки стрімкому зростанню обсягів інформаційних потоків наукових публікацій і який має значний вплив на розвиток медичної науки. В світі щорічно публікується близько 4 млн. науково-медичних статей у 20 тис. журналів [5].

Аналіз систем зберігання супровідної інформації у біобанках. Сучасні дослідження в області медицини, зокрема вивчення генетичних основ належності до складних захворювань, вимагають комплексного аналізу великого масиву клінічної інформації та молекулярно-генетичних даних, що характеризують індивідуальні особливості організму. Колекції біологічного матеріалу або біобанки, відіграють центральну роль в об’єднанні цих двох потоків інформації та консолідують велику кількість біологічних образів і супровідної інформації. Біобанки сьогодні - це новий напрям, що розвивається як самостійна область досліджень із багатьма специфічними компонентами та вимагає спеціалізованих кадрів. Біобанки є репортерами біологічних образів та асоційованої з ними інформації для ведення наукової роботи в рамках крупномасштабних, мультидисциплінарних і мультицентрових дослідницьких проектів [10, 21].

Система зберігання супровідної інформації в біобанках представляє собою складний програмнотехнічний комплекс, оптимізований для аналізу та тривалого зберігання великих обсягів біоінформатичних даних і відповідних метаданих [1].

Носії інформації для зберігання баз медичної та біологічної інформації. Вибір оптимальної технології зберігання даних може здійснюватися з використанням таких критеріїв, як вартість, довговічність та строки міграції даних. Головним обмежуючим чинником до визначення числа об’ єктів, що необхідно зберігати тривалий час, може бути вартість зберігання даних. Дослідники систем довготривалого зберігання інформації відзначають, що вартість організації процесу довготривалого зберігання даних є високою та багато в чому визначається вартістю і характеристиками використовуваних носіїв інформації. Важливим критерієм для визначення ефективності систем зберігання даних $\epsilon$ середня тривалість життя цифрових носіїв. Вибір носія 3 довготривалим строком зберігання даних для архівування цифрового контенту впливає не тільки на ціни, але також і на довгострокову безпеку об’єктів. Типові цифрові носії інформації мають очікувану тривалість життя від 3 до 10 років, хоча несправності можуть відбутися в будь-який час. Недовга тривалість життя носіїв, в поєднанні $з$ неефективними процедурами резервного копіювання, можуть призвести до втрати цифрового контенту, що підлягає довготривалому зберіганню. Третій критерій, що включає в себе термін служби носія інформації і пов’язані з цим витрати на цифрове збереження, - це строки міграції даних. Кожен цифровий носій і будь-яка цифрова система мають обмежений термін служби. В цілях збереження цифрових об'єктів за межами очікуваної тривалості життя носіїв інформації більшість цифрових носіїв інформації повинні бути поновлені або інформація регулярно переноситься на інші носії. Вартість 
переходу від одного покоління носіїв до іншого, або 3 одного виду носіїв на інший тип може бути значною. Міграція буде включати вартість нових носіїв і нових систем, але вона повинна також включати витрати на персонал керування заміною і процесом перевірки, для того щоб переконатися, що немає ніякої втрати даних або деградації [14].

Досвід використання створених баз даних медичної та біологічної інформації показує, що з метою забезпечення збереження даних необхідно періодично (залежно від швидкості заповнення бази та інтенсивності внесення нових даних) створювати архівні копії бази даних і записувати їх на оптичні диски [1]. Однак, стандартні компакт-диски можуть забезпечити гарантоване зберігання даних не більше 20 років. Найменші терміни гарантованого зберігання даних мають оптичні носії з перезаписом DVD-RW, BD-RE [17]. Недостатні строки гарантованого зберігання медичної та біологічної інформації на компакт-дисках пов'язані з особливостями технології їх виготовлення, заснованої на застосуванні підкладок з нестабільного полікарбонату, що з часом змінює фізико-хімічні властивості, особливо в процесі багаторазових відтворювань записаної інформації [9]. Зараз основною областю застосування оптичних дисків $\epsilon$ архівування даних. Для зберігання великих обсягів архівної інформації розробляють спеціальні оптичні носії. Для збільшення довговічності оптичних носіїв $з$ пластиковими підкладками запропоновано та розроблено багато технічних рішень.

Розроблялися технології підвищення строків зберігання даних на оптичних носіях різних типів. Головним напрямом підвищення надійності зберігання даних на оптичних носіях із одноразовим записом була розробка спеціальних реєструвальних середовищ. Компанії «Panasonic» та «Sony» спільно запропонували стандарт «Archival Disc» для професійного використання оптичних дисків наступного покоління [12] (рис. 1).

Значне збільшення ємності Arhival Disc порівняно з Blu-ray Disc було досягнуто шляхом застосування декількох технічних рішень. За рахунок використання шести шарів запису даних (по три на кожній стороні диску) було досягнуто значного стрибка обсягу пам'яті до 300 Гб на диск [19]. Щоб максимально збільшити обсяг зберігання даних, у кожному шарі використовується запис як у спіральних канавках (grooves), так і в проміжках між ними (lands). Використання нових оксидних реєструвальних матеріалів для запису сприяє збільшенню швидкості запису та обсягу записаних даних. Використання оксидних реєструвальних матеріалів також підвищує стійкість диску до впливу зовнішніх факторів і підвищує строк зберігання даних [19].

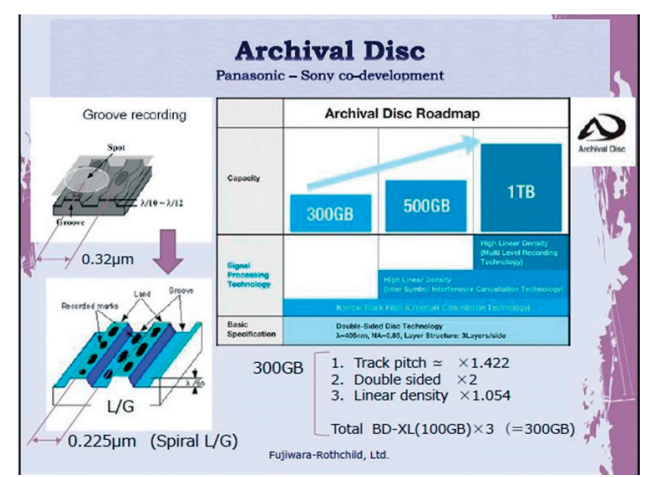

Рис. 1. Загальні відомості про архівний диск [12]

Планується збільшити ємність архівного диска до 1 Тб [20]. На новому поколінні оптичних дисків високої ємності, розроблених спільно компаніями «Sony» i «Panasonic», гарантується строк зберігання даних протягом більше 100 років. Для забезпечення довготривалого зберігання даних із строком понад 500 років створюються спеціальні професійні оптичні носії інформації, відмінною рисою яких є використання високостабільних матеріалів як підкладок та інформаційних шарів. Зокрема пропонується використовувати скляні, кварцеві та навіть металеві (нікелеві або вольфрамові) диски для довготривалого зберігання інформації. Проблема довготермінового зберігання даних вирішується створенням спеціальних оптичних носіїв інформації, в яких використовується запис даних у вигляді мікрорельєфних структур на поверхні високостабільних матеріалів $[9,18]$. Для довготермінового зберігання стратегічно важливої інформації запропоновано виготовляти підкладки оптичних носіїв із синтетичного сапфіру. Інформація на такі носії записується у широковживаних форматах i, за необхідності, може бути відтворена різними методами, наприклад, методом тунельної сканувальної мікроскопії. Базовий метод відтворення даних із таких носіїв передбачає використання стандартних пристроїв відтворення даних із компакт-дисків, в яких для компенсації двопроменезаломлення на поверхні фокусувального об'єктива розміщена тонка кварцева пластина [6, $9,18]$. Використання спеціальних оптичних носіїв дозволить значно збільшити час між проведенням міграції інформації для забезпечення гарантованого довготермінового зберігання даних і, головне, 
забезпечити довготермінове зберігання інформації про здоров’я пацієнтів.

\section{Висновки.}

1. Медична та біологічна інформація представляє значну цінність і має стратегічно важливе значення для організації лікування на сучасному рівні, переходу до персоніфікованої медицини.

2. Особливо важливе значення має довготермінове зберігання генетичної інформації, зокрема генетичного паспорту людини, що дозволяє докорінно покращити рівень діагностики та лікування.

3. Довготривале зберігання медичної та біологічної інформації може бути забезпечене на спеціальних оптичних носіях інформації, виготовлених із високостабільних матеріалів, запис даних на які зроблено у форматах стандартних компакт-дисків. Використання таких носіїв дозволить суттєво збільшити час між необхідними процесами міграції даних.

\section{Література.}

1. Базы данных коллекций биологического материала: организация сопроводительной информации / С. В. Буйкин, Е. Ю. Брагина, Л. А. Конева, В. П. Пузырёв // Бюллетень сибирской медицины. — 2012. — № 1. - С. 111-120.

2. Беликова Т. П. Автоматизированные рабочие места для анализа медицинских изображений / Т. П. Беликова // Компьютерные технологии в медицине. - 1997. — № 3. - С. 38-42.

3. Использование PACS при формировании хранилищ изображений в медицинских учреждениях / А. С. Коваленко, А. А. Пезенцали, О. А. Романюк, Е. К. Царенко // Клиническая информатика и телемедицина. - 2014. - Т. 10, Вып. 11. - С. 95-99.

4. Каперусов С. Ю. РАCS - система архивирования и передачи изображений в лучевой диагностике (краткий обзор) / С. Ю. Каперусов // Радиология практика. — 2007. — № 3. - С. 69-73.

5. Ованесян Р. Большинство наших научно-медицинских журналов не отвечает стандарту [Электронный ресурс] / Р. Ованесян // Голос Армении. — 2015. - Режим доступа : http://www.golosarmenii.am/ article/26775/bolshinstvo-nashix-nauchno-medicinskixzhurnalov-ne-otvechaet-standartu.

6. Оптические диски для долговременного хранения информации / В. В. Петров, В. М. Пузиков, А. А. Крючин, И. В. Горбов // Наносистеми, наноматеріали, нанотехнології. - 2009. — Т. 7, № 3. - С. 825-832.

7. Отдельное хранение медицинских данных и региональные информационные системы
[Электронный ресурс] / Dell EMC (блог). — 2015, 14 декабря. - Режим доступа : https://habrahabr.ru/ company/dellemc/blog/273019/.

8. Распределенный PACS [Электронный ресурс] / Лаборатория медицинских компьютерных систем. Режим доступа : https://www.multivox.ru/pacs_cloud. shtml.

9. Analysis of properties of optical carriers after long-term storage / V. V. Petrov, A. A. Kryuchin, I. V. Gorbov [et al.] // Semiconductor Physics, Quantum Electronics and Optoelectronics. - 2009. —-Vol. 12, No. 4. P. 399-402.

10. Biobanks and personalized medicine / J. E. Olson, S. J. Bielinski, E. Ryu [et al.] // Clin. Genet. — 2014. — Vol. 86, No. 1. - P. 50-55.

11. Corn M. Archiving the phenome: clinical records deserve long-term preservation / M. Corn // J. Am. Med. Inform. Assoc. - 2009. - Vol. 16, No. 1. - P. 1-6.

12. Coughlin T. Keeping data for a long time [Electronic resource] / T. Coughlin // Forbes/ - 2014, June 29. - Available at : https://www.forbes.com/sites/ tomcoughlin/2014/06/29/keeping-data-for-a-longtime/\#36caa5d715e2.

13. Eggert A. A. Long-term data storage in a clinical laboratory information system / A. A. Eggert, K. A. Emmerich // Journal of Medical Systems. 1989. - Vol. 13, No. 6. - P. 347-354.

14. Erickson C. L. Alternatives for long-term storage of digital information [Electronic resource] / C. L. Erickson, B. M. Lunt. — Available at : https://sites. lib.byu.edu/digitalpreservation/wp-content/uploads/ sites/21/2015/11/iPres_poster_2015_resubmit2Erickson_Lunt.pdf.

15. Information storage and disposal policy [Electronic resource] / Government of Western Australia. Departament of Health. - Available at : http://www. health.wa.gov.au/circularsnew/attachments/946.pdf.

16. Landenmark H.-K. E. An estimate of the total DNA in the biosphere / H.-K. E. Landenmark, D. H. Forgan, C. S. Cockell // PLoS One. — 2015. — Vol. 7.

17. Lunt B.M. How long is long-term data storage? [Electronic resource]/B. M. Lunt // Archiving 2011 Final Program and Proceedings. - P. 29-33. Available at : http://www.imaging.org/site/PDFS/Reporter/Articles/ REP26_3_4_ARCH2011_Lunt.pdf.

18. Method of aberration compensation in sapphire optical discs for the long term data storage / V. V. Petrov, V. P. Semynozhenko, V. M. Puzikov [et al.] // Functional Materials. - 2014. - Vol. 21, No. 1. - P. 105-111.

19. Optical disc archive generation 2 [Electronic resource] / Sony // White paper. — April 2016. — 24 p. — Available at : http://www.everspan.com/wp-content/ uploads/2016/04/ODA_Gen2_WhitePaper_20160408_ English.pdf.

20. OCP_Japan_Sony Panasonic_V10 20160623(Final)-1. pdf. 
21. Polašek O. Future of biobanks - bigger, longer, and more dimensional / O. Polašek // Croat. Med. J. — 2013. — Vol. 54, No. 5. - P. 496-500.

22. Resources [Electronic resource] / Personalized medicine coalition. - Available at : http://www. personalizedmedicinecoalition.org/Resources/ PersonalizedMedicine_101.

\section{References.}

1. Buikin, S. V., Bragina, E. Yu., Koneva, L. A., \& Puzyrev, V. P. (2012). Bazy dannykh kollektsii biologicheskogo materiala: organizatsiya soprovoditel'noi informatsii [Databases of collections of biological material: the organization of accompanying information]. Byulleten' sibirskoi meditsiny (Bulletin of Siberian Medicine), 1, 111-120.

2. Belikova, T. P. (1997). Avtomatizirovannye rabochie mesta dlya analiza meditsinskikh izobrazhenii [Automated workplaces for the analysis of medical images]. Komp’yuternye tekhnologii v meditsine (Computer technologies in medicine), 3, 38-42.

3. Kovalenko, A. S., Pezentsali, A. A., Romanyuk, O. A., \& Tsarenko, E. K. (2014). Ispol'zovanie PACS pri formirovanii khranilishch izobrazhenii v meditsinskikh uchrezhdeniyakh [The use of PACS in the formation of image stores in medical institutions]. Klin. informat. i telemed. (Clinical informatics and telemedicine), 10(11), 95-99.

4. Kaperusov, S. Yu. (2007). PACS - sistema arkhivirovaniya I peredachi izobrazhenii v luchevoi diagnostike (kratkii obzor) [PACS - system of archiving and transfer of images in beam diagnostics (short review)]. Radiologiya — praktika (Radiology — Practice), 3, 69-73.

5. Ovanesyan, R. (2015). Bol'shinstvo nashikh nauchnomeditsinskikh zhurnalov ne otvechaet standartu [Most of our scientific and medical journals do not meet the standard]. Golos Armenii (The Voice of Armenia). Retrieved from http://www.golosarmenii.am/ article/26775/bolshinstvo-nashix-nauchno-medicinskixzhurnalov-ne-otvechaet-standartu.

6. Petrov, V. V., Puzikov, V. M., Kryuchin, A. A., \& Gorbov, I. V. (2009). Opticheskie diski dlya dolgovremennogo khraneniya informatsii [Optical disks for long-term storage of information]. Nanosistemi, nanomateriali, nanotekhnologii (Nanosystems, Nanomaterials, Nanotechnologies), 7(3), 825-832.

7. Dell EMC (2015, December 14). Otdel'noe khranenie meditsinskikh dannykh i regional'nye informatsionnye sistemy [Separate storage of medical data and regional information systems] [Web log post]. Retrieved from https://habrahabr.ru/company/dellemc/blog/273019/.

8. Laboratoriya meditsinskikh komp’yuternykh sistem (Laboratory of Medical Computer Systems). (n. d.) Raspredelennyi PACS [Distributed PACS]. Retrieved from https://www.multivox.ru/pacs_cloud.shtml.
9. Petrov V. V., Kryuchin, A. A., Gorbov, I. V., Kossko, I. O., \& Kostyukevych, S. O. (2009). Analysis of properties of optical carriers after long-term storage. Semiconductor Physics, Quantum Electronics and Optoelectronics, 12(4), 399-402.

10. Olson J. E., Bielinski S. J., Ryu, E., Winkler, E. M., Takahashi, P.Y., Pathak, J., \& Cerhan, J. R. (2014). Biobanks and personalized medicine. Clin Genet., 86(1), 50-55. doi: 10.1111/cge.12370.

11. Corn M. (2009). Archiving the phenome: clinical records deserve long-term preservation. J. Am Med Inform Assoc., 16(1), 1-6. doi: 10.1197/jamia.M2925.

12. Coughlin T. (2014, June 29) Keeping data for a long time. Forbes. Retrieved from https://www.forbes.com/ sites/tomcoughlin/2014/06/29/keeping-data-for-a-longtime/\#36caa5d715e2.

13. Eggert, A. A., \& Emmerich, K. A. (1989). Long-term data storage in a clinical laboratory information system. Journal of Medical Systems, 13(6), 347-354.

14. Erickson, C. L., \& Lunt, B. M. (n. d.) Alternatives for long-term storage of digital information. Retrieved from https://sites.lib.byu.edu/digitalpreservation/wpcontent/uploads/sites/21/2015/11/iPres_poster_2015_ resubmit2-Erickson_Lunt.pdf.

15. Government of Western Australia. Departament of Health. (n. d.) Information storage and disposal policy. Retrieved from http://www.health.wa.gov.au/ circularsnew/attachments/946.pdf.

16. Landenmark, H.-K. E., Forgan, D. H., \& Cockell, C. S. (2015). An estimate of the total DNA in the biosphere. PLoS One, 7. doi: 10.1371/journal.pbio.1002168.

17. Lunt, B. M. (2011) How long is long-term data storage? Archiving 2011 Final Program and Proceedings (pp. 2933). Retrieved from http://www.imaging.org/site/PDFS/ Reporter/Articles/REP26_3_4_ARCH2011_Lunt.pdf.

18. Petrov, V. V., Semynozhenko, V. P., Puzikov, V. M., Kryuchyn, A. A. Lapchuk, A. S., Morozov, Ye. M. ...Shanoylo, S. M. (2014). Method of aberration compensation in sapphire optical discs for the long term data storage. Functional Materials, 21(1), 105-111. doi: org/10.15407/fm21.01.105.

19. Sony. (2016, April). Optical Disc Archive Generation 2. White paper. Retrieved from http://www.everspan. com/wp-content/uploads/2016/04/ODA_Gen2_ WhitePaper_20160408_English.pdf.

20. OCP_Japan_Sony Panasonic_V10 20160623(Final)-1. pdf.

21. Polašek O. (2013). Future of biobanks — bigger, longer, and more dimensional. Croat. Med. J., 54(5), 496-500. doi: 10.3325/cmj.2013.54.496.

22. Personalized Medicine Coalition. (n. d.). Resources. Retrieved from http://www. personalizedmedicinecoalition.org/Resources/ PersonalizedMedicine_101. 